\title{
Effects of dietary grape seed on performance and some metabolic assessments in Japanese quail with different plumage colors exposed to heat stress
}

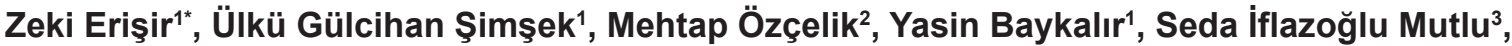 \\ Mehmet Çiftçi ${ }^{3}$
}

\author{
${ }^{1}$ University of Firat, Faculty of Veterinary Medicine, Department of Animal Science, Elazig, Turkey. \\ ${ }^{2}$ University of Firat, Vocational School of Health Services, Elazig, Turkey. \\ ${ }^{3}$ University of Firat, Faculty of Veterinary Medicine, Department of Animal Nutrition and Nutritional Diseases, Elazig, Turkey.
}

\begin{abstract}
The objective of this study was to determine the effects of grape seed (GS) supplementation to basal diet on performance, carcass characteristics, some biochemical parameters, and antioxidant status of tissues of Japanese quail in growth phase with different plumage colors exposed to heat stress (HS). A total of 144 eight-day-old Japanese quail including 72 (36 females, 36 males) grey and 72 (36 females, 36 males) golden were used in this study. The quail were kept under HS $\left(16 \mathrm{~h}\right.$ at $34{ }^{\circ} \mathrm{C}, 8 \mathrm{~h}$ at $\left.22{ }^{\circ} \mathrm{C}\right)$ and thermo-neutral $\left(24 \mathrm{~h}\right.$ at $\left.22^{\circ} \mathrm{C}\right)$ conditions between 15 and 43 days of age. All quail were fed a basal diet (control) and basal diet supplemented with GS at both $10 \mathrm{~g} / \mathrm{kg}$ and $20 \mathrm{~g} / \mathrm{kg}$ ratios. Each feeding treatment was repeated three times including four quail (two females and two males) per replicate. Heat stress considerably decreased the live weight gain on days 29-36, 36-43, and 15-43. Golden quail had higher live weight from the beginning of the trial. The increase of live weight on days 15-43 was higher in the golden group than in the grey group. Malondialdehyde (MDA) levels of liver and kidney tissues increased in heat-stress group compared with thermo-neutral group $(\mathrm{P}<0.001)$. In HS, significant increases were determined only in catalase (CAT) in the liver and in glutathione peroxidase (GSH-Px), CAT, and glutathione (GSH) in the kidney $(\mathrm{P}<0.05)$. Addition of dietary GS decreased MDA and antioxidant levels, which increased in liver and kidney of quail during HS. Plasma total cholesterol, alanine aminotransferase (ALT), and aspartate aminotransferase (AST) levels were higher in quail under HS. Plasma total cholesterol, glucose, triglyceride, AST, and ALT levels of quail under HS decreased due to addition of $10 \mathrm{~g} / \mathrm{kg} \mathrm{GS}$.
\end{abstract}

Key Words: antioxidant, feed additive, heat stress, Japanese quail

\section{Introduction}

High temperature is one of the environmental factors that influence physiological traits and production of poultry (Azad et al., 2010). Since heat stress (HS) increases reactive oxygen species, it leads to oxidative stress (Erisir et al., 2016). As a result of HS, oxidative stress increases the amount of malondialdehyde (MDA), which is an indicator of lipid peroxidation, and decreases serum, vitamin, and mineral concentrations, playing a critical role in antioxidant defense system (Çiftçi et al., 2016).

Received: July 20, 2017

Accepted: February 15, 2018

*Corresponding author: zerisir@firat.edu.tr

Copyright (c) 2018 Sociedade Brasileira de Zootecnia. This is an Open Access article distributed under the terms of the Creative Commons Attribution License (http://creativecommons.org/licenses/by/4.0/), which permits unrestricted use, distribution, and reproduction in any medium, provided the original work is properly cited.
Grape seed (GS) extract contains the most beneficial groups of plant flavonoids and oligomers of proanthocyanidin. It is reported that proanthocyanidin extracts have cholesterol lowering and anticancer effects as well as antibacterial, antiviral, and antifungal activities (Cos et al., 2003). As strong antioxidants, proanthocyanidins have numerous positive effects on health (Singh et al., 2004). Grape seed oil, which is considered to have functional property, is rich in unsaturated fatty acids, containing $72-76 \%$ of linoleic acid ratio. The oil contains a vast quantity of tannin. This level is 100 times greater than oils of other seeds. This situation makes GS oil more resistant to peroxidation. Studies on prevention of thrombosis, inhibition of cardiovascular disorders, serum cholesterol lowering, vasodilatation, and regulation of autonomic nervous system against low density lipoprotein (LDL) oxidation have revealed that grape seed oil has pharmaceutical activity (Cao and Ito, 2003) and also contains tocopherol (900-1200 ppm). As the strongest fat-soluble antioxidants, tocopherols have 
vitamin $\mathrm{E}$ activity. They have antioxidant properties 50 times greater than vitamin $\mathrm{E}$ and 20 times greater than vitamin C (Martinello et al., 2007).

Plumage color (PC) is accepted as a characteristic of the breed or line in quail. In previous studies, lines of quail are named and defined according to PC mutations. Today, new lines with different PC mutations are being explored. It is becoming important to reveal yield traits of these lines (Cneg and Kimura, 1990).

Therefore, the objective of this study was to determine the effects of GS supplementation to basal diet on weight gain, feed intake, feed conversion ratio, carcass characteristics, some biochemical parameters, and antioxidant status of liver and kidney of Japanese quail in the growth phase with different PC exposed to heat stress.

\section{Material and Methods}

The study was conducted in Elazig province (38 $40^{\prime} \mathrm{S}$, $39^{\circ} 13^{\prime} \mathrm{W}$ ) of Turkey. A total of 144 eight-day-old Japanese quail with different $\mathrm{PC}$, including 72 grey (36 females, 36 males) and 72 golden (36 females, 36 males) quail, were taken at one week of age in this study. The quail were adapted to the environment for a week. Then, they were weighed and assigned to groups when they were 15 days old. The quail were kept under heat stress (HS: $16 \mathrm{~h}$ at $34^{\circ} \mathrm{C}, 8 \mathrm{~h}$ at $22{ }^{\circ} \mathrm{C}$ ) and thermo-neutral (TN: $24 \mathrm{~h}$ at $22^{\circ} \mathrm{C}$ ) conditions between 15 and 43 days of age. All quail were fed a basal diet (control) and a basal diet supplemented with GS at both 10 and $20 \mathrm{~g} / \mathrm{kg}$ ratios. Each feeding treatment was repeated three times including four quail (two females and two males) per replicate. The local Ethical Committee on Animal Use approved all procedures used in this study (case no. 2016/23). Light was provided continuously $(24 \mathrm{~h})$ throughout the experiment. Diet and water were offered ad libitum. Rations used in the study were arranged according to the standards of National Research Council (NRC, 1994) (Table 1). Feed intake and body weight were determined weekly. The weight gain and feed conversion ratios of the quail were then calculated. Six quail (three males and three females) from each group and two quail per repetition were randomly chosen and slaughtered 43 days later. Blood, liver, heart, spleen, and kidney were resected carefully during slaughtering. Slaughter, liver, heart, and spleen weights were determined. Blood samples were taken into tubes containing heparin and centrifuged at 3,000 rpm for $10 \mathrm{~min}$ and their serum was extracted. Serum liver and kidney samples were kept at -20 until the analysis.

The serum was used for glucose, triglyceride, total cholesterol, uric acid, ALT, and AST assay. Glucose, triglyceride, total cholesterol, uric acid, alanine aminotransferase (ALT), and aspartate aminotransferase (AST) were measured by using a biochemical analyzer (Olimpus AU-600).

Malondialdehyde (MDA) levels of liver and kidney were spectrophotometrically measured in accordance with the procedures described by Placer et al. (1966). Superoxide dismutase (SOD) activity of the tissues was measured using xanthine and xanthine oxidases to generate superoxide radicals which react with nitroblue tetrazolium (NBT) based on the methods of Sun et al. (1988). The glutathione peroxidase (GSH-Px) activity was determined according to Lawrence and Burk (1976). The glutathione content of the tissues was measured at $412 \mathrm{~nm}$ by using the method of Sedlak and Lindsay (1968). Aebi (1984) method was used to measure catalase (CAT) activity.

During the data collection stage, two-way anova was used by the GLM (General Linear Model) procedure. Main effects of environmental conditions, plumage colors,

Table 1 - Ingredients and nutrient composition of experimental diets

\begin{tabular}{|c|c|c|c|}
\hline Item & Control & $10 \mathrm{~g} / \mathrm{kg} \mathrm{GS}$ & $20 \mathrm{~g} / \mathrm{kg} \mathrm{GS}$ \\
\hline \multicolumn{4}{|l|}{ Ingredient (g/kg) } \\
\hline Maize & 420.00 & 415.20 & 405.00 \\
\hline Wheat & 125.00 & 120.00 & 117.60 \\
\hline Soybean meal (48\% CP) & 250.00 & 250.00 & 250.00 \\
\hline Corn gluten $(43 \% \mathrm{CP})$ & 145.00 & 145.00 & 145.00 \\
\hline Vegetable oil & 24.70 & 24.00 & 26.60 \\
\hline Grape seed & - & 10.00 & 20.00 \\
\hline DL-methionine & 2.50 & 2.50 & 2.50 \\
\hline Calcium phosphate & 6.50 & 6.70 & 6.70 \\
\hline Ground limestone & 15.30 & 15.30 & 15.30 \\
\hline L-lysine hydrochloride & 2.60 & 2.90 & 2.90 \\
\hline L-treonine & 1.80 & 1.80 & 1.80 \\
\hline L-tryptophan & 0.10 & 0.10 & 0.10 \\
\hline $\mathrm{NaHCO}_{3}$ & 1.00 & 1.00 & 1.00 \\
\hline Salt & 2.50 & 2.50 & 2.50 \\
\hline Vitamin-mineral mix ${ }^{1}$ & 3.00 & 3.00 & 3.00 \\
\hline \multicolumn{4}{|l|}{ Nutritional composition (g/kg) } \\
\hline Dry matter & 900.00 & 900.10 & 900.10 \\
\hline Crude protein & 240.00 & 240.00 & 240.00 \\
\hline Crude cellulose & 28.30 & 30.10 & 32.00 \\
\hline Ether extract & 42.80 & 43.30 & 47.00 \\
\hline Crude ash & 54.50 & 55.20 & 55.60 \\
\hline Sugar & 50.00 & 49.00 & 50.00 \\
\hline Starch & 375.00 & 375.00 & 375.00 \\
\hline Calcium & 8.00 & 8.00 & 8.00 \\
\hline Available phosphorus & 3.00 & 3.00 & 3.00 \\
\hline Sodium & 1.80 & 1.80 & 1.80 \\
\hline Methionine + cysteine & 10.50 & 10.40 & 10.40 \\
\hline Lysine & 13.00 & 13.10 & 13.10 \\
\hline Threonine & 10.30 & 10.30 & 10.20 \\
\hline Tryptophan & 2.70 & 2.70 & 2.70 \\
\hline Metabolizable energy $(\mathrm{kcal} / \mathrm{kg})^{2}$ & 3107 & 3103 & 3107 \\
\hline \multicolumn{4}{|c|}{$\begin{array}{l}\text { GS - grape seed. } \\
{ }^{1} \text { Vitamin content supplied per kg feed: vitamin A, } 46.5 \mathrm{IU} \text {; vitamin D3, } 10.5 \mathrm{IU} \\
\text { mineral content supplied per kg: Mn, } 0.36 \mathrm{mg} ; \mathrm{Fe}, 0.12 \mathrm{mg} \text {; } \mathrm{Zn}, 0.3 \mathrm{mg} ; \mathrm{Cu}, 0.05 \mathrm{mg} \\
\mathrm{Co}, 0.6 \mathrm{mg} \text {; I, 0.004 mg; Se, } 0.001 \mathrm{mg} \text {. } \\
{ }^{2} \text { Calculated, metabolizable energy }(\mathrm{kcal} / \mathrm{kg})=53+38 \mathrm{~B} \text { used formula. B }=(\% \text { crude } \\
\text { protein })+(2.25)(\% \text { ether extract })+(1.1)(\% \text { starch })+(\% \text { sugar }) .\end{array}$} \\
\hline
\end{tabular}


and feed supplementations and interactions among the parameters were present in tables. Significant differences were further subjected to Tukey's multiple range test of SPSS (2012, version 21.0). P values less than 0.05 were accepted as significant.

\section{Results}

Heat stress considerably decreased live weight gain on days 29-36 $(\mathrm{P}<0.001), 36-43(\mathrm{P}<0.05)$, and 15-43 $(\mathrm{P}<0.05)$ (Table 2). Golden quail had higher live weight from the beginning of the trial $(\mathrm{P}<0.01)$. The live weight gain on days 15-43 was higher in golden group than in grey group $(\mathrm{P}<0.05)$. No significant effect of feed additive used was found on live weight and live weight gain $(\mathrm{P}>0.05)$. When the interaction between ambient temperature and different PC was examined, live weight gain on days 22-29 was significantly affected $(\mathrm{P}<0.05)$. When the interaction between ambient temperature and addition of feed additive was examined, live weight gain on days 29-36 and 36-43 was significantly affected $(\mathrm{P}<0.05)$. When examining the interaction between different $\mathrm{PC}$ and addition of feed additive, live weight gain on days 22-29 was significantly influenced $(\mathrm{P}<0.05)$. As the interactions among ambient temperature, different $\mathrm{PC}$, and addition of feed additive were examined, live weight gain on days 36-43 was significantly affected $(\mathrm{P}<0.01)$.

Generally, feed intake rate of quail raised under TN condition was found to be higher compared with quail raised under HS $(\mathrm{P}<0.001)$ (Table 3$)$. The rate of feed efficiency was higher on days 15-22 ( $\mathrm{P}<0.001), 22-29$ $(\mathrm{P}<0.001)$, and 15-43 $(\mathrm{P}<0.05)$ in quail raised under HS. When the interaction between different $\mathrm{PC}$ and addition of feed additive was examined, feed efficiency on days 29-36 was significantly affected $(\mathrm{P}<0.05)$. When examining the interactions among ambient temperature, different $\mathrm{PC}$, and addition of feed additive, feed efficiency rate on days 36-43 was significantly affected $(\mathrm{P}<0.05)$.

It was observed that slaughter weight was significantly higher in quail raised under normal conditions $(\mathrm{P}<0.05)$ (Table 4). Heart weight and heart ratio were significantly higher in quail raised under TN contidion compared to those raised under HS $(\mathrm{P}<0.001)$.

It was found that total cholesterol, ALT, and AST levels were higher in quail raised under heat stress $(\mathrm{P}<0.001)$ (Table 5). While triglyceride $(\mathrm{P}<0.001)$ and uric acid levels $(\mathrm{P}<0.05)$ were higher in grey quail, ALT levels $(\mathrm{P}<0.05)$ were significantly higher in the golden. Addition of GS to ration significantly decreased glucose, ALT, and AST values $(\mathrm{P}<0.001)$ compared with control group. While the addition of GS to ration significantly decreased total cholesterol $(\mathrm{P}<0.05)$, triglyceride $(\mathrm{P}<0.001)$, and uric acid $(\mathrm{P}<0.05)$ levels in quail raised under HS, it had no effect on those raised under TN condition. When the interaction between ambient temperature and different plumage color was analyzed, triglyceride and ALT values $(\mathrm{P}<0.001)$, and AST and uric acid values $(\mathrm{P}<0.01)$ were significantly influenced. When examining the interaction between ambient temperature and feed additive, it significantly affected glucose $(\mathrm{P}<0.05)$, total cholesterol $(\mathrm{P}<0.01)$, triglyceride $(\mathrm{P}<0.05)$, and AST $(\mathrm{P}<0.01)$ values.

Malondialdehyde levels of liver and kidney tissues increased in heat stress group compared with thermoneutral group $(\mathrm{P}<0.001)$ (Table 6). Catalase activity of liver $(\mathrm{P}<0.001)$ and SOD $(\mathrm{P}<0.01)$, GSH level $(\mathrm{P}<0.001)$, GSH-Px $(\mathrm{P}<0.001)$, and CAT $(\mathrm{P}<0.001)$ activities of kidney were significantly lower in heat stress group. Malondialdehyde levels of liver $(\mathrm{P}<0.01)$ and kidney $(\mathrm{P}<0.001)$ were higher in golden group. Superoxide dismutase and CAT activities $(\mathrm{P}<0.001)$ and GSH level $(\mathrm{P}<0.01)$ of liver were higher in golden group. Superoxide dismutase activity of kidney was lower and its GSH level and GSH-Px activity were higher in this group $(\mathrm{P}<0.001)$. Grape seed supplemented to diet significantly decreased MDA levels of liver and kidney $(\mathrm{P}<0.001)$. Higher CAT activity of liver and SOD, GSH-Px, and CAT activities of kidney were obtained in control (no supplement) group $(\mathrm{P}<0.01)$.

\section{Discussion}

As expected, in the study, it was observed that HS significantly decreased live weight gain. Animals under heat stress tend to diminish their heat production by limiting feed intake, with subsequent detrimental effects on live weight gain. Several researchers have also reported that HS decreased the live weight gain (Siegel, 1995; Çiftçi et al., 2013). Golden quail had higher live weight from the beginning of the trial and higher live weight gain at the end of trial. Numerous researchers reported that different PC significantly affected the live weight (Oguz and Minvielle, 2001; Genchev et al., 2008; Tarhyel et al., 2012; Inci et al., 2015). Addition of GS to ration did not affect the live weight gain in the study. Similarly, in a previous study conducted by Brenes et al. (2010) with broilers, they reported that addition of GS to ration did not affect the live weight gain. It is a known fact that temperature over normal limits decreases feed intake of animals and, accordingly, the feed efficiency. In the present study, heat stress significantly decreased feed intake. Many researchers have reported that HS 


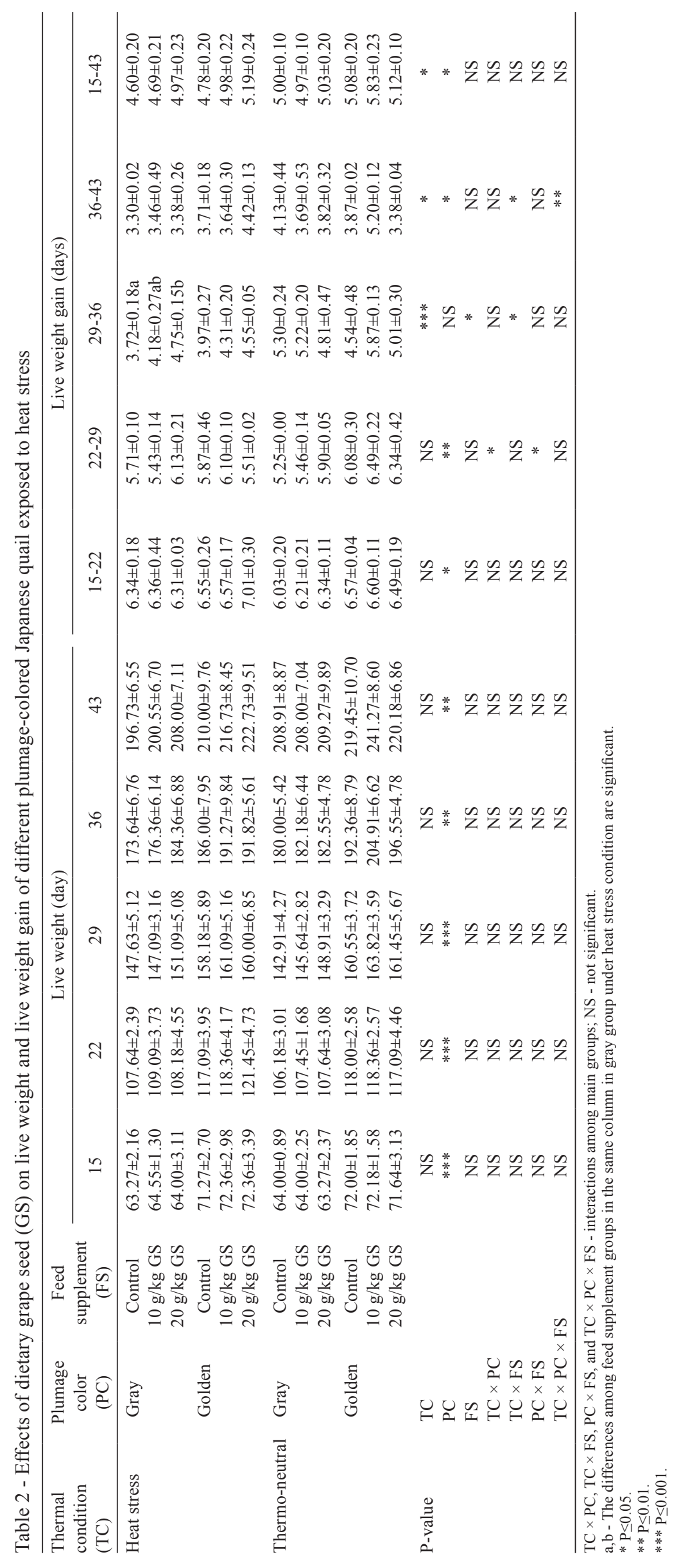




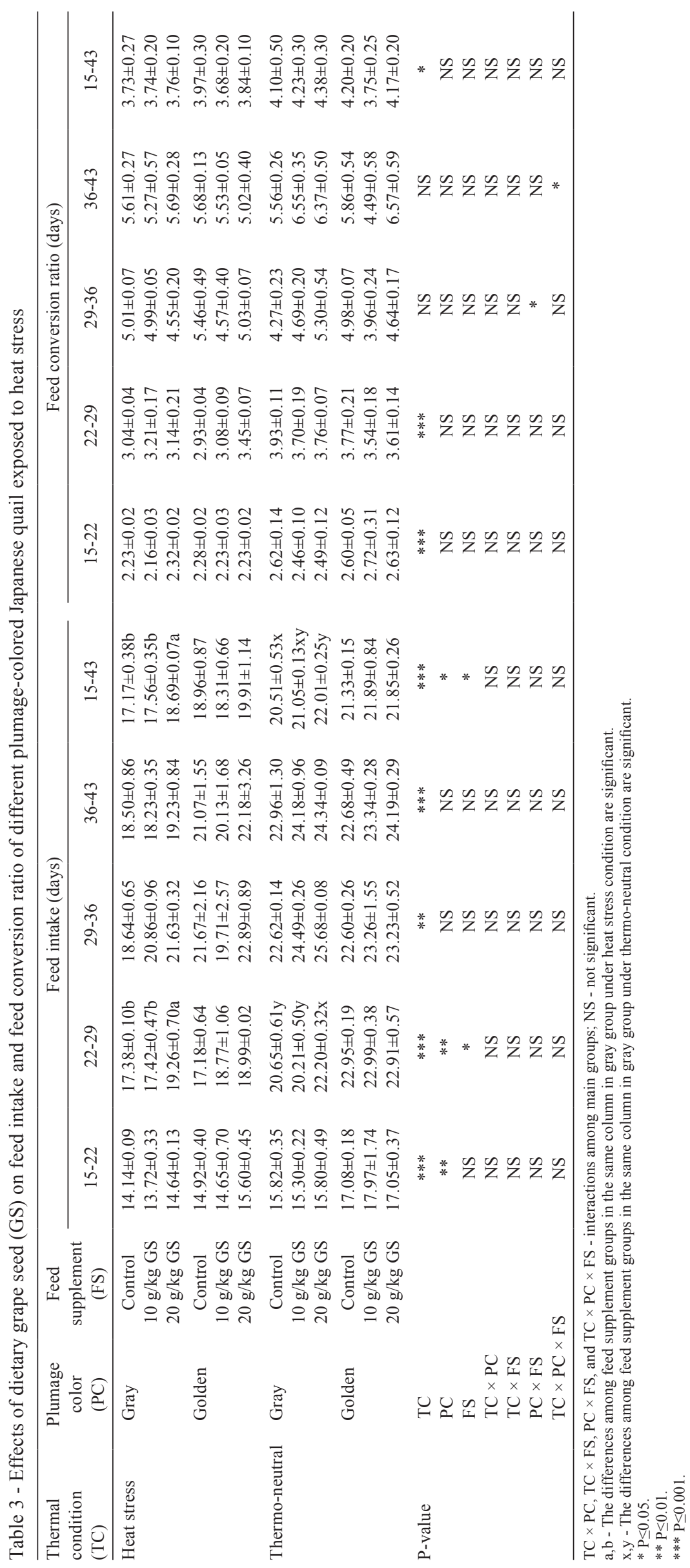


Table 4 - Effects of dietary grape seed (GS) on carcass characteristics of different plumage-colored Japanese quail exposed to heat stress

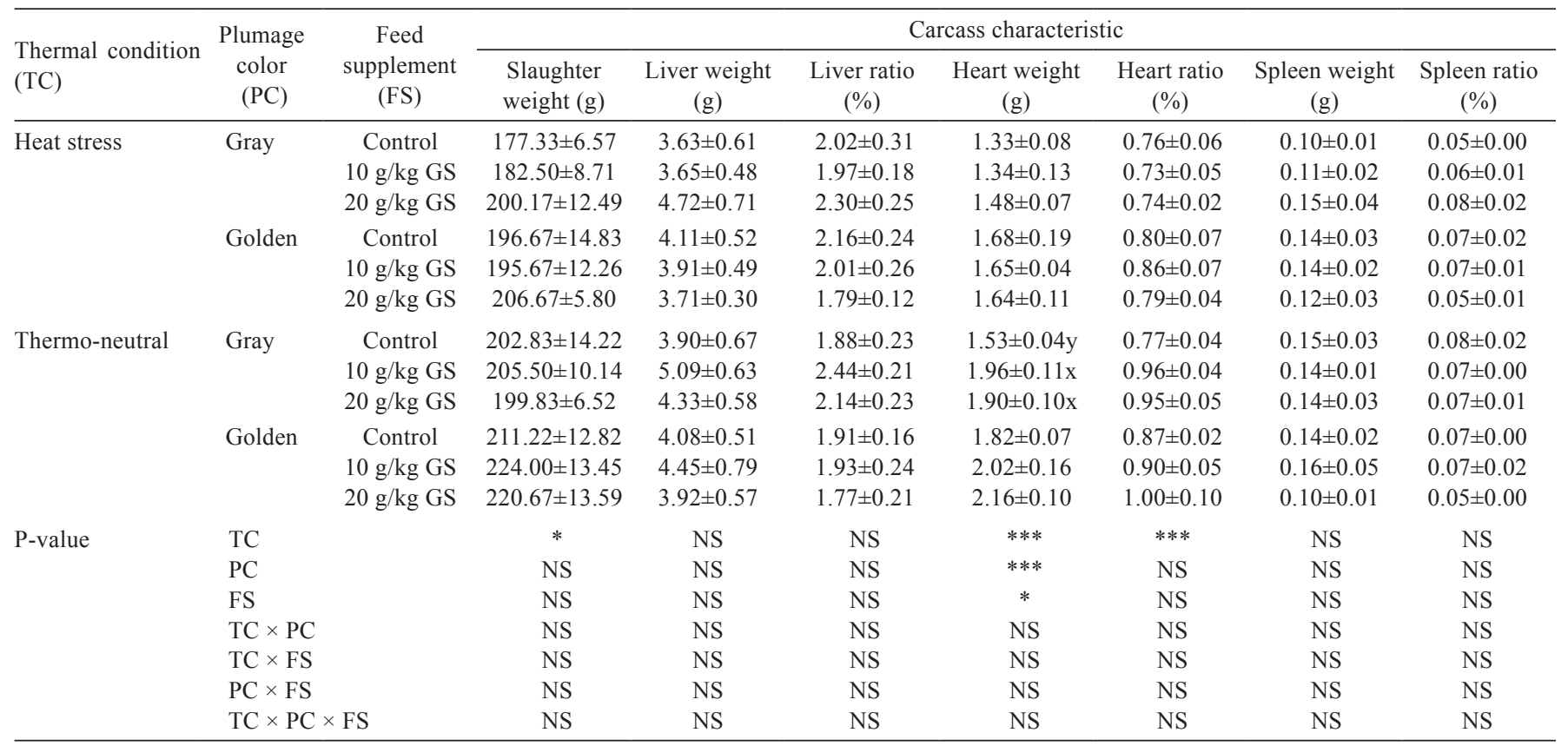

$\mathrm{TC} \times \mathrm{PC}, \mathrm{TC} \times \mathrm{FS}, \mathrm{PC} \times \mathrm{FS}$, and $\mathrm{TC} \times \mathrm{PC} \times \mathrm{FS}-$ interactions among main groups; NS - not significant.

$\mathrm{x}, \mathrm{y}-\mathrm{The}$ differences among feed supplement groups in the same column in gray group under thermo-neutral condition are significant.

$* \mathrm{P} \leq 0.05$.

$* * * \mathrm{P} \leq 0.001$.

Table 5 - Effects of dietary grape seed (GS) on blood parameters of different plumage-colored Japanese quail exposed to heat stress

\begin{tabular}{|c|c|c|c|c|c|c|c|c|}
\hline \multirow{2}{*}{$\begin{array}{l}\text { Thermal condition } \\
\text { (TC) }\end{array}$} & \multirow{2}{*}{$\begin{array}{l}\text { Plumage } \\
\text { color } \\
\text { (PC) }\end{array}$} & \multirow{2}{*}{$\begin{array}{c}\text { Feed } \\
\text { supplement } \\
\text { (FS) }\end{array}$} & \multicolumn{6}{|c|}{ Blood parameter } \\
\hline & & & $\begin{array}{l}\text { Glucose } \\
(\mathrm{mg} / \mathrm{dL})\end{array}$ & $\begin{array}{l}\text { Total cholesterol } \\
(\mathrm{mg} / \mathrm{dL})\end{array}$ & $\begin{array}{l}\text { Triglyceride } \\
(\mathrm{mg} / \mathrm{dL})\end{array}$ & $\begin{array}{c}\text { ALT } \\
(\mathrm{mg} / \mathrm{dL})\end{array}$ & $\begin{array}{l}\text { AST } \\
(\mathrm{U} / \mathrm{L})\end{array}$ & $\begin{array}{l}\text { Uric acid } \\
(\mathrm{mg} / \mathrm{dL})\end{array}$ \\
\hline \multirow[t]{6}{*}{ Heat stress } & Gray & Control & $203.33 \pm 6.82 \mathrm{a}$ & $376.45 \pm 4.82 \mathrm{a}$ & $125.83 \pm 3.24 \mathrm{a}$ & $8.50 \pm 0.22$ & $303.83 \pm 9.65 \mathrm{a}$ & $6.32 \pm 0.22 \mathrm{a}$ \\
\hline & & $10 \mathrm{~g} / \mathrm{kg} \mathrm{GS}$ & $184.00 \pm 4.48 b$ & $324.47 \pm 9.49 b$ & $112.17 \pm 4.66 b$ & $8.17 \pm 0.48$ & $249.17 \pm 9.97 b$ & $3.98 \pm 0.40 b$ \\
\hline & & $20 \mathrm{~g} / \mathrm{kg} \mathrm{GS}$ & $187.67 \pm 2.74 \mathrm{ab}$ & $348.36 \pm 8.88 \mathrm{ab}$ & $100.00 \pm 2.18 \mathrm{~b}$ & $7.17 \pm 0.54$ & $281.50 \pm 13.71 \mathrm{ab}$ & $4.62 \pm 0.17 b$ \\
\hline & Golden & Control & $202.50 \pm 5.42$ & $384.66 \pm 8.80 \mathrm{~A}$ & $115.33 \pm 3.60 \mathrm{~A}$ & $13.00 \pm 1.29 \mathrm{~A}$ & $357.00 \pm 4.66 \mathrm{~A}$ & $5.50 \pm 0.53$ \\
\hline & & $10 \mathrm{~g} / \mathrm{kg} \mathrm{GS}$ & $196.83 \pm 5.23$ & $354.90 \pm 4.13 \mathrm{~B}$ & $106.17 \pm 4.10 \mathrm{~B}$ & $11.00 \pm 1.39 \mathrm{AB}$ & $272.33 \pm 15.10 \mathrm{~B}$ & $5.50 \pm 0.39$ \\
\hline & & $20 \mathrm{~g} / \mathrm{kg} \mathrm{GS}$ & $200.17 \pm 6.75$ & $354.03 \pm 8.36 \mathrm{~B}$ & $100.83 \pm 3.49 \mathrm{~B}$ & $8.33 \pm 0.56 \mathrm{~B}$ & $296.50 \pm 14.73 B$ & $5.00 \pm 0.38$ \\
\hline \multirow[t]{6}{*}{ Thermo-neutral } & Gray & Control & $217.00 \pm 7.91 x$ & $327.44 \pm 3.84$ & $134.17 \pm 5.52$ & $7.00 \pm 0.58 x$ & $266.33 \pm 5.49 x y$ & $6.43 \pm 0.62$ \\
\hline & & $10 \mathrm{~g} / \mathrm{kg} \mathrm{GS}$ & $176.33 \pm 5.64 y$ & $331.07 \pm 6.55$ & $120.67 \pm 5.20$ & $3.33 \pm 0.67 \mathrm{y}$ & $245.83 \pm 6.50 \mathrm{y}$ & $6.28 \pm 0.44$ \\
\hline & & $20 \mathrm{~g} / \mathrm{kg} \mathrm{GS}$ & $174.50 \pm 6.73 y$ & $335.86 \pm 5.89$ & $126.50 \pm 4.71$ & $5.00 \pm 0.73 x y$ & $278.00 \pm 8.99 x$ & $5.60 \pm 0.35$ \\
\hline & Golden & Control & $210.17 \pm 7.91$ & $336.72 \pm 7.09$ & $98.33 \pm 5.13$ & $6.17 \pm 1.07 \mathrm{X}$ & $255.50 \pm 9.20$ & $4.88 \pm 0.62$ \\
\hline & & $10 \mathrm{~g} / \mathrm{kg} \mathrm{GS}$ & $200.00 \pm 5.64$ & $335.70 \pm 6.02$ & $92.83 \pm 2.78$ & $3.67 \pm 0.33 \mathrm{Y}$ & $234.83 \pm 10.54$ & $4.87 \pm 0.23$ \\
\hline & & $20 \mathrm{~g} / \mathrm{kg} \mathrm{GS}$ & $178.00 \pm 8.44$ & $333.56 \pm 5.97$ & $95.33 \pm 4.81$ & $3.17 \pm 0.48 Y$ & $257.67 \pm 12.42$ & $4.42 \pm 0.29$ \\
\hline \multirow[t]{7}{*}{ P-value } & $\mathrm{TC}$ & & NS & $* * *$ & NS & $* * *$ & $* * *$ & NS \\
\hline & $\mathrm{PC}$ & & NS & NS & $* * *$ & $*$ & NS & $*$ \\
\hline & FS & & $* * *$ & $*$ & $* * *$ & $* * *$ & $* * *$ & $*$ \\
\hline & $\mathrm{TC} \times \mathrm{PC}$ & & NS & NS & $* * *$ & $* * *$ & $* *$ & $* *$ \\
\hline & $\mathrm{TC} \times \mathrm{FS}$ & & $*$ & $* *$ & $*$ & NS & $* *$ & NS \\
\hline & $\mathrm{PC} \times \mathrm{FS}$ & & NS & NS & NS & NS & NS & NS \\
\hline & $\mathrm{TC} \times \mathrm{PC}$ & & NS & NS & NS & NS & NS & NS \\
\hline
\end{tabular}

ALT - alanine aminotransferase; AST - aspartate aminotransferase; TC $\times$ PC, TC $\times$ FS, PC $\times$ FS, and TC $\times$ PC $\times$ FS - interactions among main groups; NS - not significant. a,b - The differences among feed supplement groups in the same column in gray group under heat stress condition are significant.

A,B - The differences among feed supplement groups in the same column in golden group under heat stress condition are significant.

$\mathrm{x}, \mathrm{y}$ - The differences among feed supplement groups in the same column in gray group under thermo-neutral condition are significant.

$\mathrm{X}, \mathrm{Y}$ - The differences among feed supplement groups in the same column in golden group under thermo-neutral condition are significant.

$* \mathrm{P} \leq 0.05$.

$* * \mathrm{P} \leq 0.01$.

$* * * \mathrm{P} \leq 0.001$. 


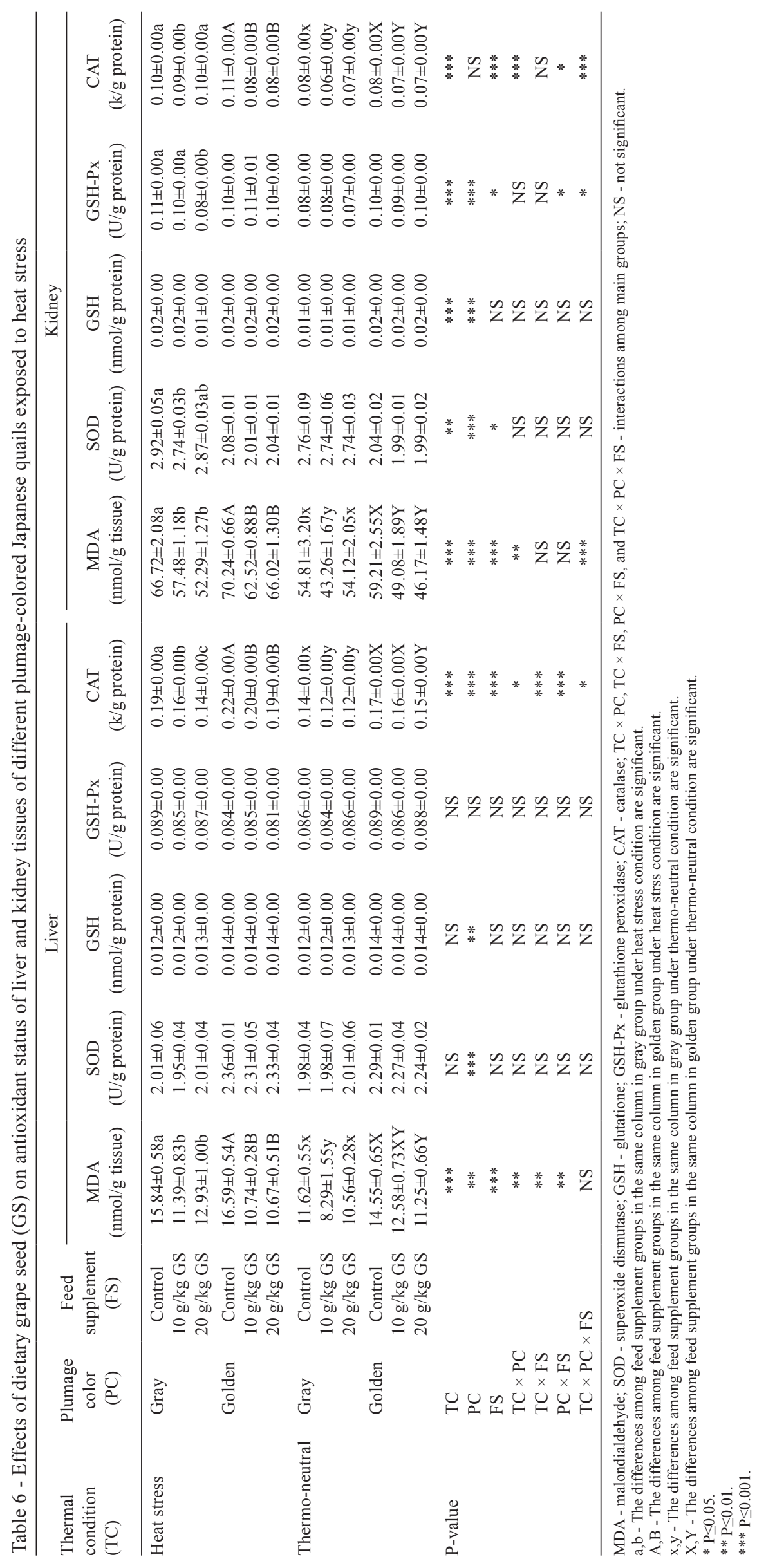


decreased feed intake (Geraert et al., 1996; Guo et al., 2003; Tawfeek et al., 2014). Austic (1985) indicated that every $10{ }^{\circ} \mathrm{C}$ of increase over $20{ }^{\circ} \mathrm{C}$ of temperature in the air decreased feed intake by $17 \%$. At the end of trial, feed efficiency rate was significantly higher in quail raised under normal conditions. Several studies indicating that heat stress affected feed efficiency rate negatively support the present study (Bartlett and Smith, 2003; Gonzalez-Esquerra and Leeson, 2005; Tawfeek, 2014). When feed intake was examined at the end of the trial, it was observed that golden quail consumed significantly greater amounts of feed than grey quail; however, feed efficiency did not change between the two groups. In the study conducted by Inci et al. (2015) with quail, they reported that feed intake was higher in golden quail, but feed efficiency did not change. Addition of GS (expecially the $20 \mathrm{~g} / \mathrm{kg}$ group) to ration significantly increased feed intake particularly in grey quail compared with the goden group, but feed efficiency did not change in the present study.

When slaughter weight was examined, it was determined that quail raised under normal conditions were significantly heavier compared with quail exposed to HS. Gonzalez-Esquerra and Leeson (2005) and Çiftçi et al. (2013) also reported that HS negatively affected live weight. Heart weight of quail raised under TN conditon was higher than that of quail exposed to HS. No difference was observed between the groups in terms of liver and spleen weights. However, in a study conducted by Bartlett and Smith (2003) with broilers, they stated that HS decreased organ weight. While color difference significantly affected heart weight in quail, it did not have an effect on slaughter weight and weights of other organs. Addition of GS to ration significantly increased heart rate and did not affect the slaughter weight and weights of other organs. In their study, Brenes et al. (2010) reported results similar to the results of present study.

In poultry, heat stress is one of the major factors causing the increased production of mitochondrial reactive oxygen species (ROS) in tissues. Reactive oxygen species accumulating in the cells cause cellular dysfunction by inducing an irreversible damage in molecules such as lipids, proteins, and DNA (Kikusato et al., 2016; Azad et al., 2013). Malondialdehyde is one of the metabolic products of lipid peroxides resulting from lipid peroxidation reaction induced by ROS in tissues (Xiao et al., 2016). Acute heat exposure $\left(32{ }^{\circ} \mathrm{C}\right.$ for $6 \mathrm{~h}$ or 32,35 , and $38{ }^{\circ} \mathrm{C}$ for $3 \mathrm{~h}$ ) resulted in a significant elevation of MDA in the liver of broiler chickens (Lin et al., 2006; Tan et al., 2010). Levels of MDA also significantly increased in livers of ducks $\left(34{ }^{\circ} \mathrm{C}\right.$, for 28 days) and quail $\left(34^{\circ} \mathrm{C}\right.$, for $8 \mathrm{~h} /$ day/12 weeks) exposed to high heat (Sahin et al., 2010; Ma et al., 2014). In the present study, the fact that HS increased MDA levels in liver and kidney of quail was an indicator of oxidative damage. Scavenging of ROS and protection of cells from oxidative damage are based on antioxidant systems of the body. Antioxidant systems contain antioxidant enzymes like GSH-Px and low molecular weight antioxidants such as GSH (Xiao et al., 2016). Exposing broilers to an acute heat shock leads to an increase in the activity of antioxidant enzymes such as SOD, GSH-Px, and CAT to protect cells from the negative consequences of excessive generation of free radicals (Lin et al., 2006; Tan et al., 2010). In the present study, significant elevations were determined only in CAT in the liver of quail and in all of the examined antioxidants in their kidney. The increase of all of these antioxidants in the kidney of quail and greater elevation of MDA indicated that more ROS was formed in kidney during HS, and kidney was more affected. There are also studies indicating that antioxidants are lower in livers of ducks, broilers, and quail exposed to high heat, and chronic HS leads to deficiency of antioxidants (Sahin et al., 2010; El-Damrawy, 2014; Ma et al., 2014).

It was identified in the present study that oxidant and antioxidant values varied in tissues based on PC of quail, and MDA levels and antioxidant values (except for SOD in kidney) in both liver and kidney of golden group were higher compared with the grey group. Higher MDA levels of liver and kidney in golden group made us reason that grey quail were more resistant to HS. Similarly, erythrocyte GSH and MDA levels were found lower in melanic (darker) falcons and eagles in a previous study (Galván et al., 2010). Vitousek et al. (2013) also stated that darker swallows had lower plasma oxidative damage and were resistant to oxidative stress, and PC based on melanine was a reliable indicator for susceptibility to oxidative stress.

Grape seeds are a rich source of flavonoid and phenolic compounds, which are strong free radical scavengers. Dietary grape seed extract significantly decreased ROS and MDA levels increasing in skeletal muscle and liver of broiler chickens exposed to chronic heat stress (Azad et al., 2013; El-Damrawy, 2014) and increased total antioxidant capacity of broiler (Farahat et. al. 2017). Addition of dietary grape seed also decreased MDA and antioxidant levels, which were elevated in liver and kidney of quail exposed to HS; grape seed both decreased the need for antioxidants and inhibited oxidative damage due to its antioxidant properties.

Thermal stress causes changes in biochemical blood parameters. Aspartate aminotransferase and ALT enzymes are released into the bloodstream in case of tissue damage 
(Gasparino et al., 2015). In the present study, HS led to a significant increase in serum AST and ALT values of quail. These results were in parallel to oxidative damage occurring in liver and kidney. Plasma triglyceride, cholesterol, and glucose levels of quail elevated in high ambient temperature (Tuzcu et al., 2008; El-Kholy et al., 2017). Increased plasma cholesterol and glucose levels were associated with high levels of plasma corticosterone resulting from stress (El-Kholy et al., 2017). In the present study, it was found that only plasma cholesterol levels significantly increased and glucose levels were normal under HS. Researchers associated chronic stress-induced hypoglycemia in poultry with exhaustion of hepatic glycogen storage following increased glucose need and elevated glycolysis (Freeman et al., 1984; Erisir and Erisir, 2002).

El-Damrawy (2014) reported that serum triglyceride, HDL, and LDL levels increased in broilers under heat stress; however, they decreased as a result of addition of GS extract. In the present study, plasma glucose, total cholesterol, triglyceride, AST, and ALT levels of quail under heat stress decreased due to addition of GS. Abu Hafsa and Ibrahim (2018) reported that GS extract decreased plasma glucose, total lipids, trigliceride, and cholesterol, but did not affect plasma ALT and AST levels. In addition, it was reported that GS showed hepatoprotective and nephroprotective effect in a previous research (Madi Almajwal and Farouk Elsadek, 2015).

\section{Conclusions}

Because of its positive effects on welfare of birds under stress conditions, grape seed can be used as a feed additive to quail feeds.

\section{Acknowledgments}

We thank to commercial company Naturoil Food and Chemical Industry Company Limited, Corum, Turkey.

\section{References}

Abu Hafsa, S. H. and Ibrahim, S. A. 2018. Effect of dietary polyphenolrich grape seed on growth performance, antioxidant capacity and ileal microflora in broiler chicks. Journal of Animal Physiology and Animal Nutrition 102:268-275. https://doi.org/10.1111/jpn.12688

Aebi, H. 1984. Catalase in vitro. Methods Enzymology 105:121-126.

Austic, R. E. 1985. Feeding poultry in hot and cold climates. p.123-136. In: Stress physiology in livestock. Vol. 3. Yousef, M. K., ed. CRC press, Boca Raton, Florida, USA.

Azad, M. A.; Kikusato, M.; Maekawa, T.; Shirakawa, H. and Toyomizu, M. 2010. Metabolic characteristics and oxidative damage to skeletal muscle in broiler chickens exposed to chronic heat stress. Comparative Biochemistry and Physiology. Part A, Molecular \& Integrative Physiology 155:401-406.

Azad, M. A.; Kikusato, M.; Zulkifli, I. and Toyomizu, M. 2013. Electrolysed reduced water decreases reactive oxygen speciesinduced oxidative damage to skeletal muscle and improves performance in broiler chickens exposed to medium-term chronic heat stress. British Poultry Science 54:503-509.

Bartlett, J. R. and Smith, M. O. 2003. Effects of different levels of zinc on the performance and immunocompetence of broilers under heat stress. Poultry Science 82:1580-1588.

Brenes, A.; Viveros, A.; Goñi, I.; Centeno, C.; Saura-Calixto, F. and Arija, I. 2010. Effect of grape seed extract on growth performance, protein and polyphenol digestibilities, and antioxidant activity in chickens. Spanish Journal of Agricultural Research 8:326-333.

Cao, X. and Ito, Y. 2003. Supercritical fluid extraction of grape seed oil and subsequent separation of free fatty acids by high-speed counter-current chromatography. Journal of Chromatography A 1021:117-124

Cneg, K. M. and Kimura, M. 1990. Poultry breeding and genetics. p.333-362. In: Mutations and major variants in Japanese quail. Crawford, R. D., ed. Elsevier, Amsterdam.

Cos, P.; De Bruyne, N.; Hermans, S.; Apers, D.; Berghe, V. and Vlietink, A. J. 2003. Proanthocyanidins in health care current and new trends. Current Medicinal Chemistry 10:1345-1359.

Çiftçi, M.; Şimşek, Ü. G.; Azman, M. A.; Çerçi, İ. H. and Tonbak, F. 2013. The effects of dietary rosemary (Rosmarinus officinalis L.) oil supplementation on performance, carcass traits and some blood parameters of japanese quail under heat stressed condition. Kafkas Universitesi Veteriner Fakültesi Dergisi 19:595-599.

Çiftçi, M.; Şimşek, Ü. G.; Dalkılıç, B.; Azman, M. A.; Yılmaz, Ö.; Mutlu, S. İ.; Özçelik, M.; Baykalır, Y.; Tonbak, F. and Bahşi, M. 2016. Effect of dietary orange peel extract on physiological, biochemical, and metabolic responses of Japanese quail reared under low ambient temperature. Turkish Journal of Veterinary and Animal Sciences 40:288-297.

El-Damrawy, S. Z. 2014. Effect of grape seed extract on some physiological changes in broilers under heat stress. Egyptian Poultry Science Journal 34:333-343.

El-Kholy, M. S.; El-Hindawy, M. M.; Alagawany, M.; Abd El-Hack, M. E. and El-Sayed, S. A. 2017. Dietary supplementation of chromium can alleviate negative impacts of heat stress on performance, carcass yield, and some blood hematology and chemistry indices of growing Japanese quail. Biological Trace Element Research 179:148-157. https://doi.org/10.1007/s12011-017-0936-Z

Erisir, M. and Erisir, Z. 2002. Changes in some biochemical blood parameters of quails (Coturnix coturnix japonica) with increasing stocking density. Turkish Journal Veterinary Animal Science 26:491-496.

Erisir, Z.; Mutlu, S. İ.; Şimşek, Ü. G.; Çiftçi, M.; Azman, M. A.; Benzer, F. and Erisir, M. 2016. Effects of milk thistle (Silybum marianum) seed supplementation to high-calorie basal diets of quails on egg production, egg quality traits, hatchability and oxidative stress parameters. Kafkas Universitesi Veteriner Fakültesi Dergisi 22:577-584.

Farahat, M. H.; Abdallah, F. M.; Ali, H. A. and Hernandez-Santana, A. 2017. Effect of dietary supplementation of grape seed extract on the growth performance, lipid profile, antioxidant status and immune response of broiler chickens. Animal 11:771-777.

Freeman, B. M.; Kettlewell, P. J.; Manning, A. C. C. and Berry, P. S. 1984. Stress of transportation for broilers. Veterinary Record 114:286-287.

Galván, I.; Gangoso, L.; Grande, J. M.; Negro, J. J.; Rodríguez, A.; Figuerola, J. and Alonso-Alvarez, C. 2010. Antioxidant machinery differs between melanic and light nestlings of two polymorphic raptors. PLoS One 5:e13369. 
Gasparino, E.; Voltolini, D. M.; Del Vesco, A. P.; Marcato, S. M.; Zancanela, V.; De Oliveira Grieser, D.; De Souza Khatlab, A.; Guimarães, S. E. and De Oliveira Neto, A. R. 2015. Thermal stress induces changes in gene expression and blood parameters in high and low feed efficiency meat quail. Journal of Applied Genetics 56:253-260.

Genchev, A.; Michavlov, G.; Ribanski, S.; Pavlov, A. and Kabakchiev, M. 2008. Meat quality and composition in Japanese quails. Trakia Journal of Sciences 6:72-82.

Geraert, P. A.; Padilha, J. C. and Guillaumin, S. 1996. Metabolic and endocrine changes induced by chronic heat exposure in broiler chickens: growth performance, body composition, and energy retention. British Journal of Nutrition 75:195-204.

Gonzalez-Esquerra, R. and Leeson, S. 2005. Effects of acute versus chronic heat stress on broiler response to dietary protein. Poultry Science 84:1562-1569.

Guo, Y.; Zhang, G.; Yuan, J. and Nie, W. 2003. Effect of source and level of magnesium and vitamin $\mathrm{E}$ on prevention of hepatic peroxidation and oxidative deterioration of broiler meat. Animal Feed Science and Technology 107:143-150.

Inci, H.; Söğüt, B.; Şengül, T.; Şengül, A. Y. and Taysi, M. R. 2015. Comparison of fattening performance, carcass characteristics, and egg quality characteristics of Japanese quails with different feather colors. Revista Brasileira de Zootecnia 44:390-396.

Kikusato, M.; Nakamura, K.; Mikami, Y.; Mujahid, A. and Toyomizu, M. 2016. The suppressive effect of dietary coenzyme Q10 on mitochondrial reactive oxygen species production and oxidative stress in chickens exposed to heat stress. Animal Science Journal 87:1244-1251.

Lawrence, R. A. and Burk, R. F. 1976. Glutathione peroxidase activity in selenium-deficient rat liver. Biochemical and Biophysical Research Communications 71:952-958.

Lin, H.; Decuypere, E. and Buyse, J. 2006. Acute heat stress induces oxidative stress in broiler chickens. Comparative Biochemistry and Physiology-Part A: Molecular \& Integrative Physiology 144:11-17.

Ma, X.; Lin, Y.; Zhang, H.; Chen, W.; Wang, S.; Ruan, D. and Jiang, Z. 2014. Heat stress impairs the nutritional metabolism and reduces the productivity of egg-laying ducks. Animal Reproduction Science 145:182-190.

Madi Almajwal, A. and Farouk Elsadek, M. 2015. Lipid-lowering and hepatoprotective effects of Vitis vinifera dried seeds on paracetamol-induced hepatotoxicity in rats. Nutrition Research Practice 9:37-42.

Martinello, M.; Hecker, G. and Pramparo, M. D. C. 2007. Grape seed oil deacidification by molecular distillation:analysis of operative variables influence using the responce surface methodology. Journal of Food Engineering 81:60-64.
NRC - National Research Council. 1994. Nutrient requirements of poultry. 9th rev. ed. National Academy Press, Washington, DC.

Oguz, I. and Minvielle, F. 2001. Effect of genetics and breeding on carcass and meat quality of Japanese quail: A review. p.63-68. In: Proceedings of 15th European Symposium on the Quality of Poultry Meat. WPSA Turkish Branch Kusadasi-Turkey.

Placer, Z. A.; Cushman, L. and Johnson, B. C. 1966. Estimation of products of lipid peroxidation (malonyl dialdehyde) in biological fluids. Analytical Biochemistry 16:359-364.

Sahin, K.; Orhan, C.; Tuzcu, M.; Ali, S.; Sahin, N. and Hayirli, A. 2010. Epigallocatechin-3-gallate prevents lipid peroxidation and enhances antioxidant defense system via modulating hepatic nuclear transcription factors in heat-stressed quails. Poultry Science 89:2251-2258.

Sedlak, J. and Lindsay, R. H. 1968. Estimation of total protein bound and non-protein sulfhydryl groups in tissue with Ellman reagent. Anal Biochemistry 25:192-205.

Siegel, H. S. 1995. Stress, strains and resistance. British Poultry Science 36:3-22.

Singh, R. P.; Tuagi, A. K.; Dhanalakshmi, S.; Agarwal, R. and Agarwal, C. 2004. Grape seed extract inhibits advanced human prostate tumor growth and angiogenesis and upregulates insulinlike growth factor binding protein-3. International Journal of Cancer 108:733-740.

Sun, Y.; Oberley, L. W. and Li, Y. 1988. A simple method for clinical assay of superoxide dismutase. Clinical Chemistry 34:497-500.

Tan, G. Y.; Yang, L.; Fu, Y. Q.; Feng, J. H. and Zhang, M. H. 2010. Effects of different acute high ambient temperatures on function of hepatic mitochondrial respiration, antioxidative enzymes, and oxidative injury in broiler chickens. Poultry Science 89:115-22.

Tarhyel, R.; Tanimomo, B. K. and Hena, S. A. 2012. Effect of sex, colour and weight group on carcass characteristics of Japanese quail. Scientific Journal of Animal Science 1:22-27.

Tawfeek, S. S.; Hassanin, K. M. A. and Youssef, I. M. I. 2014. The Effect of dietary supplementation of some antioxidants on performance, oxidative stress, and blood parameters in broilers under natural summer conditions. Journal World's Poultry Research 4:10-19.

Tuzcu, M.; Sahin, N.; Karatepe, M.; Cikim, G.; Kilinc, U. and Sahin, K. 2008. Epigallocatechin-3-gallate supplementation can improve antioxidant status in stressed quail. British Poultry Science 49:643-648.

Vitousek, M. N.; Stewart, R. A. and Safran, R. J. 2013. Female plumage colour influences seasonal oxidative damage and testosterone profiles in a songbird. Biology Letters 9(5):20130539.

Xiao, X.; Yuan, D.; Wang, Y. X. and Zhan, X. A. 2016. The Protective effects of different sources of maternal selenium on oxidative stressed chick embryo liver. Biological Trace Element Research 172:201-208. 